\title{
Diaspora as a Repercussion of Colonization in the Kim Scott's
}

\section{'Benang'}

\author{
Chaitra Nagammanavar \\ Assistant Professor \\ Department of Studies in English \\ Bangalore University \\ Bangalore, Karnataka, India \\ chaitramn30@gmail.com
}

\begin{abstract}
Colonization created upheavals around the world. The worlds of Native Americans, Australian Aboriginals which were unaware of the other world that existed were shattered and scattered by the colonial rule. The indigenous people were subjected to cruel treatment at the hands of colonizers. In the Americas the mass killings of the natives took place by intentional spreading of the epidemics. Same incidents took place in Australia. The colonial rule always invented novel ways to destroy the native people, culture and their society. For instance, the policy of Doctrine of lapse which was introduced in India destroyed the local rulers and the princely states. Due to this many princely states in India came under the rule of British. In Australia to eliminate aboriginals the white government came up with the idea of assimilation policy. Assimilation policy was a policy of absorbing aboriginal people onto white society through the process of removing children from their aboriginal families forcefully. The ultimate intent of the policy was the destruction of Aboriginal society. The protagonist of the novel Benang is the victim of this process. He also goes through the
\end{abstract}


diasporic experiences of alienation, isolation and loss of identity. This paper analyses the diaspora as a repercussion of colonization in the novel Benang.

Keywords -Diaspora, Aboriginals, Colonial, Diaspora and Repercussion.

\section{Introduction}

The Criminal Tribes Act in India introduced by the British which made the tribes in India difficult to roam. They were classified as criminals and the women were raped and abused by the British officers. The hard life of the Indian tribes could be seen in the novel The Victim by Vibhavari Shirurkhar. The indigenous culture's encounter with the colonial powerswhether it's in Americas, Australia or India has always resulted in clash between two cultures. The cause for this is the imposition of culture on the natives by colonial powers. These colonial powers claimed that they were superior to the natives. The colonizers claimed that they were superior to the natives as they were civilized and God had 'sent' them to civilize the 'others'. This resulted in the creation of binaries: white-black, civilizeduncivilized, master-slave or good-bad. As a result, colonizers occupied superior status to the colonized natives. They became the 'center' and 'self' whereas the natives became the 'marginalized' and 'others' on their own lands. This process also had other ways of destroying the native culture such as mass killing of natives, removing children from the aboriginal families and breeding out of the color which were mainly followed in Australia. Kim Scott's Benang traces the reconstruction of a continuity of the broken aboriginal culture by the colonial powers. It also portrays the racist policy of the colonialists towards the natives, violation of the rights of natives, elimination of aboriginal population through biological and cultural assimilation in the White Australian society.

2. Forcible Assimilation of Aboriginals into White society in Australia 
The protagonist belongs to the Nyoongar family. It deals with the real incident which took place between 1910 to 1970 . The indigenous children in Australia were forcibly removed from their families and communities. Later they were adopted by the non-indigenous or the white people. This is one of the ways adopted by the colonizers to eradicate the aboriginal population. The other way of eradicating aboriginal population was by 'breeding out of the colour' that is biological assimilation, marriage of aboriginal women with the white men.

\section{Facts in the Fiction: Benang}

'Benang: From the Heart' is a novel based on the real incident of forced assimilation of aboriginals into white society. This is also autobiographical in nature. Kim Scott before writing this novel did a research work on his family lineage for five years as he is also a product and victim of forced assimilation. Harley is the protagonist of the novel. He makes an effort to know his forefathers by going through government documents and old photographs. This also portrays the diasporic elements such as unbelongingness, alienation, identity crisis, hybridity and isolation.

\section{Diaspora as a Repercussion of Colonization}

Hitherto, Diaspora literature referred to dispersion of Israelites or Jews out of their ancestral homeland and their subsequent settlement in other parts of the globe. Diaspora is nothing but a large group of people with a similar heritage or homeland who have moved out to places all over the world. The term 'Diaspora' which has its roots in Greek refers to 'scattered seeds'. In recent days due to heightened growth of globalization there is lot of maneuvering of people for jobs and business to different countries. So there has been a great deal of scattering of people worldwide. This has led to phenomena like cultural conflict, hyphenation, alienation, divided self, double consciousness, nostalgia and multiculturalism.

Though Harley lived in the country where his ancestors were born he felt like an expatriate. The identity crisis among the expatriates is abundant. They are stuck in the middle of the sea, 
even when they have two shores but do not belong to both. The atrocity of Whites on aboriginals was so much that they scattered whole families throughout Australian continent. Harley too grows up as a White Australian in a White Australian family but later he starts to discover he is not a White Australian. He grows up with his grandfather Earnest Solomon Scat is a Scottish White. He starts to reconcile with his whole life about not being a white but of an aboriginal origin. Harley abandons all works and goes on to discover his real identity:

And it was the subsequent search for the biological family of one of my girlfriends that so much trouble began, and led me to reconsider who I am. (Kim Scott, Benang 19)

His grandfather is on the project of examining the progress of assimilation project taken up by the White government. Harley acts as a specimen for his project. Harley also starts the counter-project of rediscovering his Nyoongar ancestry. Harley always had a strange feeling filling inside him:

a whiteness which was surface only, with no depth and very little variation He even felt the strangeness as he was made to lie on an iron cot. Growing up, he felt like a stranger growing within himself. He could see the dark blue veins under the skin and his loins covered with napkins. He watched the changing shape with horror and every time he felt more and stranger to himself (Kim Scott, Benang 13,14).

He did not turn biologically completely white. Now and then he felt strange about his own body. Also deep inside his mind he knew he did not belong to white community.

Harley asserts that though his skin color has turned white he doesn't belong to the white society. He also feels that how much his first aboriginal forefather was no white even he is no white man:

Sandy One was no white man. Just as I am no white man, despite the look of me (Kim Scott, Benang 497) 
Harley's identity crisis is so much that he feels he is an object to curiosity. They don't look at him as a normal human being. This also portrays his alienation from his society:

Yes, I am something of a curiosity- even for my own people (Kim Scott, Benang 495)

The emotion of unbelongingness with his world around is also a trait of diasporic literature. Harley feels that even when he is grown up as white and having whitish color he doesn't belong to white the culture or society:

Raised to carry on one heritage, and ignore another, I find myself wishing to reverse that upbringing, not only for the sake of my children, but also for my ancestors, and for their children in turn. And therefore, inevitably most especially, for myself (Kim Scott, Benang 21)

Like in other diasporic works hybridity is the result of consensual assimilation of peoples of two different cultures but in this novel the hybridity is due to forced assimilation of aboriginals with the White people because the White government in Australia wanted to eradicate the aboriginal population from Australia.

Breeding Up. In the third or fourth generation no sign of native origin is apparent. The repetition of the boarding school process and careful breeding... after two or three generations the advances should be living like the rest of the community(Kim Scott, Benang 26)

Kim Scott not only speaks about biological and cultural destruction of the aboriginals but also the destruction of their language. Harley grown up in the white community was unaware of the white's discrimination on the aboriginals. He was startled to see the different labels such as full-blood, half-caste (first cross), quadroon, octoroon given to aboriginals. The caption given to Harley's father's photograph was: 
Octoroon grandson (mother quarter caste [No. 2], father Kim Scottish). Freckles onthe face are the only trace of colour apparent(Kim Scott, Benang 28).

The change was so pronounced that he felt that he himself looked just a fraction of what he would have really been like Harley also speaks of the atrocities committed by the whites towards the aboriginal women.

Harley, while tracing his family's history, got confused. He saw photographs of the daughters of Daniel and Harriet with their White husbands. Many White men married Nyoongar women and looked after their children but, at the same time, there were Aboriginal children who were abandoned by the white fathers. Em himself had raped a native woman on the day of his arrival to Australia. Harley's father too had abandoned his Aboriginal mother. When Harley examined the documents, he found many of the photographs missing. Harley felt that the photos were deliberately removed by some member of the family to hide the birth of a Black child. Harley feels:

My family, my people have done such things. Shown such shame and self-hatred (Kim Scott, Benang 99).

Isolation is another important characteristic in diaspora literature. The people start feeling they are different from the world around them and they start isolating themselves from the outer world. This can be seen in the instances of Aboriginal children going to school where they were put in a crowded classroom. Large strength of white children scared them and they were easy targets of White children. They were humiliated and treated as objects of curiosity. For instance the aboriginal children Kathleen and Jack were teased by the White children:

Pooh, pooh, they cried, and they held their noses up in the air. What a smell, what a stink, such perfume. Nigger nigger pull the trigger bang bang bang (Kim Scott, Benang 290) 
The cause for isolation is not only aboriginals but also the white people. The white parents wanted the aboriginal children to be kept separate from rest of the white children. In contrary to the credit the whites take for giving equal opportunities for untouchables, the whites in Australia created some sort of 'untouchability' and caste system. This is also a kind of racial segregation we find in many of the diasporic novels. They created several classifications among aboriginals such as full-blood, half-caste (first cross), quadroon, octoroon given to aboriginals. Based on the classification they were treated differently. Jack is estranged from a means of expression. Jack becomes isolated, which makes him vulnerable to colonial, racist discourse. Jack's is a metaphor for the Nyoongar community's silence for the violence inflicted on them. His chatter had enabled him to form connections with the world and his family and given him a narrative authority, which in turn had offered him a sense of belonging, identity and agency.

There is isolation, alienation and loss of identity in Jack. When an aboriginal tradition of corroboree takes place, Jack isolates from others. After being silent for some time, Jack shouts, "No, no, not me" (99). The corroboree is weird and strange to him. In contrast to Jack, Harley is close to Nyoongar tradition and practices. He is less alienated to Nyoongar community.

5. Conclusion

On the whole Kim Scott brings to light the incidents which were ignored in the history of Australia. He expresses the plight of his community: their isolation, alienation, unbelongingness towards the whole society. The biological experiments of breeding out of colour, racial segregation and discrimination of aboriginals by the whites. The word 'aboriginal' means original people of that land; in contrary to this meaning the aboriginals are living the life of expatriates in their own country where they really belong. The white government forcefully assimilated them and also segregates them from the mainstream. Kim 
Scott puts in effort to bring out the glorious customs, tradition and languages of aboriginals. Through his characters in Benang he portrays the difficulties of the aboriginals. Through this work he rewrites the history of the colonial past of the Australian continent and portrays the diasporic experiences of the aboriginals in their own country. 


\section{Works Cited}

Scott, Kim. Benang: From the Heart,Fremantle. Fremantle Arts Centre. 1999. Print.

Bhabha, Homi. The Location of Culture. London: Routledge, 2000. Print.

Shirurkar, Vibhavari. The Victim. Tr. Yashodhara Maitra. Sahitya Akademi. 2006. Print.

Jain, Jasbir, ed. Writers of the Indian Diaspora: Theory and Practice. Jaipur: Rawat, 1998. 